\title{
RANCANG BANGUN ALAT PENYEDIA PIRING PORTABLE
}

\author{
${ }^{(1)}$ Dianita Wardani, ${ }^{(2)}$ Tianur, ${ }^{(3)}$ Aditya Kosasih \\ (1)Program Studi Teknik Mesin, Politeknik Caltex Riau \\ (2)(3) Program Studi Teknik Mekatronika, Politeknik Caltex Riau \\ Email :dianita@pcr.ac.id
}

\begin{abstract}
Abstrak
Perkembangan teknologi saat ini semakin pesat dengan perkembangan teknologi, terdapat banyak alat yang diciptakan untuk membantu pekerjaan manusia bertujuan agar lebih efektif dan efisien. Penelitian ini membahas tentang Alat Penyedia Piring Portable yang dapat digunakan di restaurant, rumah makan. Alat ini bertujuan untuk menyediakan piring tambahan untuk diletakkan di rumah makan, agar pengunjung lebih mudah untuk mendapatkan piring tambahan apabila membutuhkan piring secara cepat untuk beberapa alasan seperti piring tambahan buat saus, nasi dan sambal. Selain itu digunakan untuk meletakkan sisa makanan seperti tulang ikan. Penginputan pada alat ini dilakukan menggunakan keypad dengan sistem elektronika menggunakan Arduino Uno. Alat ini mengakomodir pemesanan tambahan piring sebanyak 6 piring, piring yang dapat di simpan oleh alat sebanyak 12 piring. Setiap pemasukan piring tambahan penginputan melalui keypad. Proses penjepitan menggunakan metode mekanik, menggunakan motor linear yang terhubungkan dengan lift transport yang digerakkan menggunakan motor wiper. Alat ini mampu mengangkat piring dengan berat 9,6 kg dalam waku 2 menit 30 detik, sedangkan untuk piring dengan berat 3,2 kg alat ini membutuhkan waktu 1 menit 30 detik. Keberhasilan alat penyedia piring portable untuk mencekam piring sebesar $90 \%$.
\end{abstract}

Kata Kunci : portable, motor linear, lift transport, motor wiper

\begin{abstract}
The development of technology is currently increasingly rapid with the development of technology, there are many tools created to help human work aimed to be more effective and efficient. This research discusses the Portable Plate Provider that can be used in restaurants, restaurants. This tool aims to provide additional plates to be placed in restaurants, so that visitors are easier to get additional plates if you need a plate quickly for several reasons such as additional plates for sauce, rice and chili sauce. Also used to put food scraps like fish bones. Input on this tool is done using a keypad with an electronic system using Arduino Uno. This tool accommodates additional orders of 6 dishes, plates that can be stored by the tool as many as 12 plates. Each additional input plate input through the keypad. The clamping process uses a mechanical method, using a linear motor connected to a transport lift that is driven using a wiper motor. This tool is able to lift plates weighing $9.6 \mathrm{~kg}$ in 2 minutes 30 seconds, while for plates weighing $3.2 \mathrm{~kg}$ this tool takes 1 minute 30 seconds. The success of portable plate providers for gripping plates is $90 \%$.
\end{abstract}

Keywords : portable, linear motor, lift transport, wiper motor 


\section{PENDAHULUAN}

Rumah makan adalah suatu usaha yang diyakini sebagai salah satu bentuk usaha ekonomi yang memiliki prospek yang cukup bagus, bahkan dalam posisi krisis sekalipun. Namun sering kali ada usaha yang terjadinya suatu gulung tikar akibat tidak mampu mempertahankan jumlah pengunjungnya. Menyebutkan bahwa terjadinya suatu kesuksesan usaha dibidang pelayanan makanan dan minuman ini tidak hanya ditentukan oleh jumlah pengunjungnya, tetapi ditentukan oleh kemampuan meningkatkan pertumbuhan pelanggannya.

Hasil survei MasterCard bertajuk Consumer Purchasing Priorities mencatat, sebanyak $80 \%$ orang Indonesia lebih memilih restoran cepat saji untuk mereka kunjungi. Angka ini kemudian diikuti $6 \%$ orang memilh pusat jajanan dan $22 \%$ orang memiliki restaurant dan kafe kelas menengah. Sedangkan, restoran jamuan makan resmi hanya 1\%.Group Country Manager (Indonesia,Malaysia dan Brunei) dan Group head Islamic Payment South East Asia MasterCard mengatakan mayoritas orang Indonesia memiliki restoran cepat saji karena menyajikan berbagai menu makanan yang unik dan lezat. Sebelum memilih tempat makan, sebesar 58\% konsumen ini biasanya menetatpkan pilihan restoran dari hasil informasi mulut ke mulut atau rekomendasi dari teman dan keluarga dan sekitar $11 \%$ konsumen memilih restoran dari hasil promosi yang ditawarkan oleh restoran tersebut. ${ }^{[1]}$

Adanya penyediaan piring yang dilakukan sebelumnya disediakan dalam bentuk rak piring secara mekanik, membuat pelanggan mengambil piring secara mandiri dan kurangnya sistem keamanan pada rak piring.

\section{METODE PENELITIAN}

\section{Perancangan Sistem Diagram Blok}

Dalam perancangan suatu sistem diperlukan diagram blok yang dapat menjelaskan seluruh kerja sistem dari awal hingga akhir, agar sistem yang dibuat dapat bekerja sesuai yang diharapkan. Berikut diagram Blok penelitian. ${ }^{[2]}$

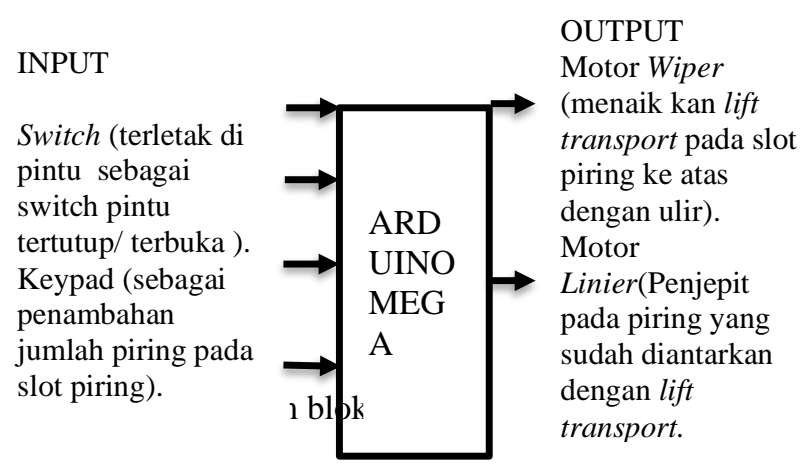

\section{Perancangan Mekanik}

Perancangan sistem Rancang bangun Penyedia Piring portable dengan Kontrol Arduino ${ }^{[3]}$. Secara garis besar akan dijelaskan melalui mekanik sebagai berikut:

a. Desain Mekanik

Perancangan desain pada penelitian ini adalah Alat Penyedia Piring Portable dengan Arduino dapat dilihat dari Gambar 2.2. adalah impelemntasi dari sistem yang dibuat serta pengujian dari sistem yang dibuat.

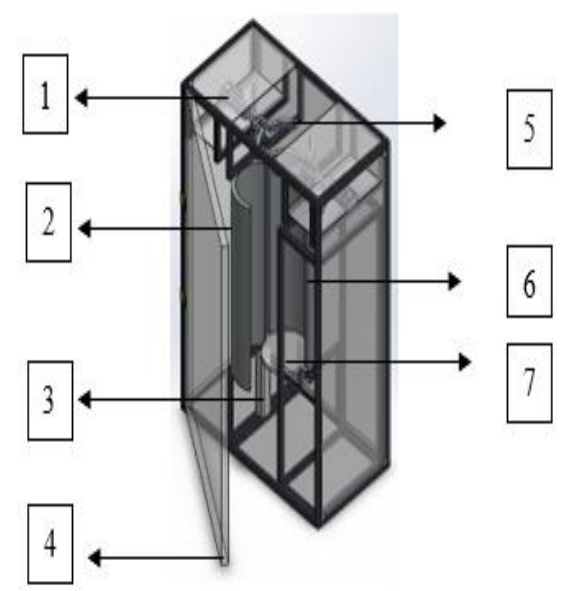

Gambar 2. 2 Isometri Alat Penyedia Piring Portable 
Keterangan:

1. Motor Linear

2. Pintu Pembuka Slot Piring

3. Motor Wiper

4. Pintu Base

5. Mekanik Penjepit Piring

6. Motor Linear

7. Pintu Pembuka Slot Piring

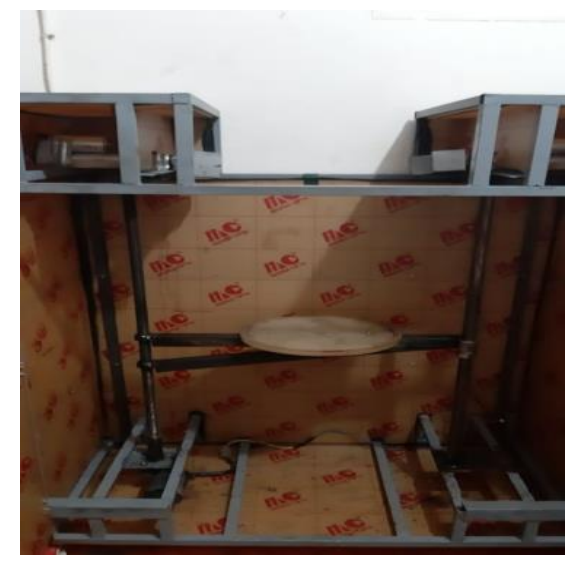

Gambar 2.3 Hasil Rancangan Alat Penyedia Piring Portable

\section{HASIL DAN PEMBAHASAN}

1. Pengujian Data Tanpa Beban

Pengujian ini dilakukan untuk mengetahui berapa lama mesin dapat bergerak ke atas tanpa beban dari piring. Berikut adalah data pengujian tanpa beban dapat dilihat pada Tabel 3.1

Tabel 3.1 Data tanpa beban dengan jarak $30 \mathrm{~cm}$

\begin{tabular}{|c|c|c|c|c|}
\hline No & Jarak & Beban & $\begin{array}{c}\text { Jumlah } \\
\text { Piring }\end{array}$ & Waktu \\
\hline 1 & \multirow{5}{*}{$\begin{array}{l}30 \\
\mathrm{~cm}\end{array}$} & \multirow{5}{*}{$0 \mathrm{~kg}$} & \multirow{5}{*}{$0 \mathrm{pcs}$} & $1: 30$ \\
\hline 2 & & & & $1: 20$ \\
\hline 3 & & & & $1: 22$ \\
\hline 4 & & & & $1: 19$ \\
\hline 5 & & & & $1: 23$ \\
\hline \multicolumn{4}{|c|}{ Rata-rata } & $1: 18$ \\
\hline
\end{tabular}

Tabel 3.2 Data tanpa beban dengan jarak $20 \mathrm{~cm}$

\begin{tabular}{|c|c|c|c|c|}
\hline No & Jarak & Beban & $\begin{array}{c}\text { Jumlah } \\
\text { Piring }\end{array}$ & Waktu \\
\hline 1 & 20 & $0 \mathrm{~kg}$ & Opcs & $0: 45$ \\
\cline { 1 - 2 } & \begin{tabular}{c} 
cm \\
\cline { 4 - 5 }
\end{tabular} & & $0: 50$ \\
\hline
\end{tabular}

\begin{tabular}{|l|l|l|}
\hline 3 & \multirow{4}{*}{} & $0: 32$ \\
\hline 4 & & $0: 39$ \\
\hline 5 & & $0: 42$ \\
\hline & & $0: 45$ \\
\hline
\end{tabular}

Tabel 4.4 Data tanpa beban dengan jarak $10 \mathrm{~cm}$

\begin{tabular}{|c|c|c|c|c|}
\hline No & Jarak & Beban & $\begin{array}{l}\text { Jumlah } \\
\text { Piring }\end{array}$ & Waktu \\
\hline 1 & \multirow{5}{*}{$\begin{array}{l}10 \\
\mathrm{~cm}\end{array}$} & \multirow{5}{*}{$0 \mathrm{~kg}$} & \multirow{5}{*}{ Opcs } & $0: 25$ \\
\hline 2 & & & & $0: 30$ \\
\hline 3 & & & & $0: 32$ \\
\hline 4 & & & & $0: 19$ \\
\hline 5 & & & & $0: 22$ \\
\hline & \multicolumn{3}{|c|}{ Rata - rata } & $0: 25$ \\
\hline
\end{tabular}

Berdasarkan data yang didapatkan, diperoleh rata-rata waktu yang dihasilkan berbeda-beda untuk proses pengangkatan piring dengan variasi jarak 10, 20 dan $30 \mathrm{~cm}$. Data waktu yang didapatkan berdasarkan 5 kali percobaan memiliki perbedaan dikarenakan kemampuan motor dalam mengangkat beban tidak sama dalam setiap percobaan. Hal ini dipengaruhi oleh beberapa faktor seperti arus yang masuk ke motor yang digunakan terus menerus dan pergerakan ulir yang kadang macet. ${ }^{[3]}$ Sehingga waktu pengangkatan piring ke atas tidak konstan. Pada penelitian dapat kita ketahui bahwa besar kecepatan dari alat penyedia piring portable ini adalah besar jarak berbanding terbalik dengan waktu. Semakin besar jarak pengujian maka semakin besar waktu yang dibutuhkan alat penyedia piring portable untuk membawa piring.

\section{Percobaan Pengujian Alat} Menggunakan Beban

Pengujian ini dilakukan untuk mengetahui berapa lama waktu yang dibutuhkan mesin pada saat proses pengangkatan piring dengan beban dan jumlah piring yang bervariasi. Piring yang digunakan memiliki berat 0,8 
$\mathrm{kg} / \mathrm{pcs}$. Data pengujian dengan beban dapat dilihat pada Table 4.4 - Tabel 4.6

Tabel 4.4 Data dengan beban 3,2 Kg.

\begin{tabular}{|c|c|c|c|c|}
\hline No & Jarak & Beban & $\begin{array}{c}\text { Jumlah } \\
\text { Piring }\end{array}$ & Waktu \\
\hline 1 & \multirow{5}{*}{$\begin{array}{l}30 \\
\mathrm{~cm}\end{array}$} & \multirow{5}{*}{$3,2 \mathrm{~kg}$} & \multirow{5}{*}{$4 \mathrm{pcs}$} & $1: 10$ \\
\hline 2 & & & & $1: 13$ \\
\hline 3 & & & & $1: 12$ \\
\hline 4 & & & & $1: 15$ \\
\hline 5 & & & & $1: 19$ \\
\hline & \multicolumn{3}{|c|}{ Rata - rata } & $1: 16$ \\
\hline
\end{tabular}

Tabel 4.5 Data dengan beban 6,4 Kg.

\begin{tabular}{|c|c|c|c|c|}
\hline No & Jarak & Beban & $\begin{array}{c}\text { Jumlah } \\
\text { Piring }\end{array}$ & Waktu \\
\hline 1 & \multirow{5}{*}{$\begin{array}{l}30 \\
\mathrm{~cm}\end{array}$} & \multirow{5}{*}{$6,4 \mathrm{~kg}$} & \multirow{5}{*}{$8 \mathrm{pcs}$} & $1: 30$ \\
\hline 2 & & & & $1: 35$ \\
\hline 3 & & & & $1: 46$ \\
\hline 4 & & & & $1: 32$ \\
\hline 5 & & & & $1: 35$ \\
\hline 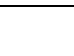 & \multicolumn{3}{|c|}{ ta - rata } & $1: 35$ \\
\hline
\end{tabular}

Tabel 4.6 Data dengan beban 9,6 Kg.

\begin{tabular}{|c|c|c|c|c|}
\hline No & Jarak & Beban & $\begin{array}{l}\text { Jumlah } \\
\text { Piring }\end{array}$ & Waktu \\
\hline 1 & \multirow{5}{*}{$\begin{array}{l}30 \\
\mathrm{~cm}\end{array}$} & \multirow{5}{*}{$9,6 \mathrm{~kg}$} & \multirow{5}{*}{$12 \mathrm{pcs}$} & $2: 18$ \\
\hline 2 & & & & $2: 12$ \\
\hline 3 & & & & $1: 52$ \\
\hline 4 & & & & $2: 02$ \\
\hline 5 & & & & $1: 56$ \\
\hline & \multicolumn{3}{|c|}{ Rata - rata } & $2: 15$ \\
\hline
\end{tabular}

Berdasarkan data yang telah didapatkan pada tabel 3.4 - 3.6. Terlihat bahwa data waktu yang dibutuhkan akan semakin besar sebanding dengan penambahan beban piring yang diberikan. Pada penelitian dapat diketahui saat beban piring yang diangkat sebanyak 4 buah dengan jarak yang berbeda-beda tetap akan membutuhkan waktu yang relatife lebih cepat dibandingkan dengan pemberian beban 8 dan 12 piring. Hal ini dikarenakan motor akan bekerja dan membutuhkan torsi yang lebih besar untuk mengangkat beban yang lebih besar, sehingga membutuhkan waktu yang relatife lebih lama. Selain itu kecepatan alat dalam memberikan

\section{Pengujian}

Keberhasilan

\section{Pengambilan Piring}

Pengujian ini dilakukan untuk mengetahui apakah limit switch bekerja dengan baik dalam menghitung jumlah piring yang di inginkan pengguna berdasarkan inputan dari keypad. ${ }^{[4]}$

Tabel 3.7 Data Pengambilan Piring

\begin{tabular}{|c|c|c|c|}
\hline No. & $\begin{array}{c}\text { Keypad } \\
\text { yang } \\
\text { ditekan }\end{array}$ & $\begin{array}{c}\text { Jumlah } \\
\text { piring } \\
\text { yang } \\
\text { dicekam }\end{array}$ & keterangan \\
\hline 1. & \multirow{5}{*}{2} & 2 & berhasil \\
\hline 2. & & 2 & berhasil \\
\hline 3. & & 2 & berhasil \\
\hline 4. & & 2 & berhasil \\
\hline 5. & & 2 & berhasil \\
\hline 1. & \multirow{5}{*}{3} & 3 & berhasil \\
\hline 2. & & 3 & berhasil \\
\hline 3. & & 3 & berhasil \\
\hline 4. & & 4 & $\begin{array}{c}\text { Tidak } \\
\text { berhasil }\end{array}$ \\
\hline 5. & & 3 & berhasil \\
\hline \multicolumn{3}{|c|}{ entase Keberhasilan } & $90 \%$ \\
\hline
\end{tabular}

Berdasarkan Tabel 3.7 dilakukan sebanyakan 10 kali percobaan data pengambilan piring berdasarkan masukan dari keypad, dan didapatkan hasil bahwa jumlah piring yang diinginkan sudah sesuai dengan data yang diinput atau dimasukan pada keypad.

Pada data prcobaan yang didapat dari penelitian menunjukan bahwa ketepatan pencekam mengambil piring sebesar 90\% dengan dua variasi pengujian piring yang dicekam sebanyak 2 piring dan 3 piring, terdapat satu kali percobaan yang tidak berhasil. Hal ini dikarenakan peletakkan piring yang tidak sesuai 
sehingga pencekam tidak mencekam piring dengan sempurna.

\section{KESIMPULAN}

Pada penelitian yang telah dilakukan, maka didapatkan kesimpulan bahwa waktu yang dibutuhkan untuk mengangkat piring semakin bertambah dengan penambahan beban piring yang diminta. Alat penyedia piring portable sudah berhasil mencekam piring sebesar $90 \%$. Alat ini mampu mengangkat piring dengan berat $9,6 \mathrm{~kg}$ dalam waku 2 menit 30 detik, sedangkan untuk piring dengan berat $3,2 \mathrm{~kg}$ alat ini membutuhkan waktu 1 menit 30 detik.

\section{REFERENSI}

[1] Tribunnews.com, (2016). Dasar teori rumah makan.

[2] Syahrul,(2015).Motor Wiper Teknologi, Metoda, dan Rangkaian Kontrol. Teknik Komputer,Universitas Komputer Indonesia, Bandung, Indonesia.

[3] Chowdhury,Kumar,Kalita,Tammi,K akoty, (2017). Motor linier, Design Algoritma, Analisis dan Kontrol LSRM,Rekenteiden Mekaniikka.

[4] Zonaelektro.net (2015). Teori Motor Wiper,Jenis dan Prinsip KerjaWiper.Implementasinya, Yogjakarta : Graha Ilmu 